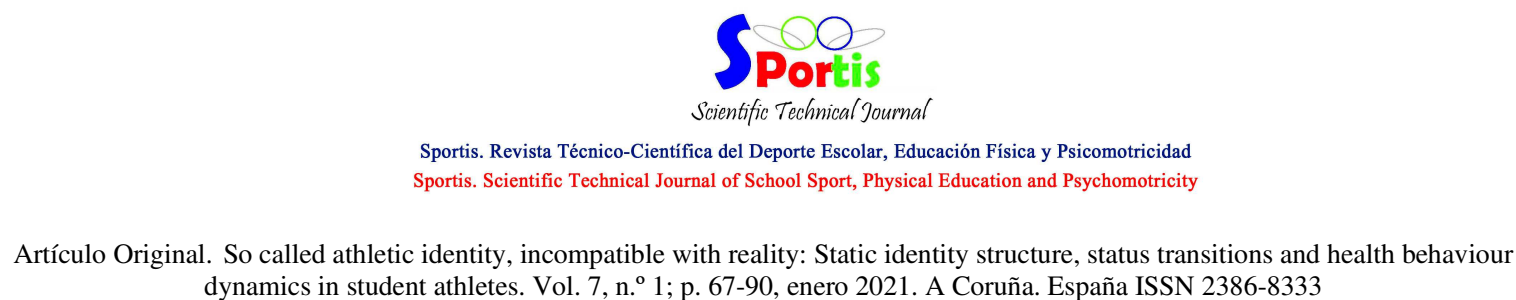
dynamics in student athletes. Vol. 7, n. ${ }^{\circ}$ 1; p. 67-90, enero 2021. A Coruña. España ISSN 2386-8333

\title{
So called athletic identity, incompatible with reality: Static identity structure, status transitions and health behaviour dynamics in student athletes
}

\section{La llamada identidad atlética, incompatible con la realidad: Estructura de identidad estática, transiciones de estado y dinámica de comportamiento de salud en estudiantes deportistas}

\author{
Berkcan Boz ${ }^{1}$; Olcay Kiremitci ${ }^{1}$ \\ ${ }^{1}$ Department of Physical Education and Sports Teaching, Faculty of Sport Sciences, \\ Ege University, Turkey \\ Contact: olcaykiremitci@gmail.com
}

Cronograma editorial: Artículo recibido: 18/08/2020 Aceptado: 14/12/2020 Publicado: 01/01/2021

https://doi.org/10.17979/sportis.2021.7.1.6918

\section{Acknowledgements}

This study was presented as oral presentation in 17th International Sport Sciences Congress, Antalya, Turkey, 2019 November and published in abstract book of the congress. There is no conflict of interest and no funding support for this study. We, authors, would like to thank all participants.

\section{Resumen}

El objetivo del presente estudio es examinar la identidad atlética y la dinámica de comportamiento relacionada con la salud de los estudiantes atletas. Se utilizó el modelo de encuesta descriptiva y 398 personas participaron en el presente estudio. Los datos fueron recolectados por la Escala de Medición de Identidad Atlética (AIMS), formulario de información, clasificación y preguntas cualitativas cerradas. Según los hallazgos, se encontró que las transiciones francas de los estudiantes aumentaron en los procesos. Por el contrario, los análisis ANOVA no muestran diferencias en las puntuaciones de identidad atlética según las calificaciones ( $p>.05$ ). Se observó un aumento en los comportamientos de salud desadaptativos $(\mathrm{p}<.05)$. Además, los comportamientos de salud desadaptativos aumentan después de la finalización del deporte y el comienzo de la universidad. Se concluyó como resultado del estudio que la aceptación de la identidad atlética de los individuos se vuelve continua a pesar de los cambios en su carrera y estados de participación deportiva; sin embargo, los comportamientos de salud no son compatibles con esta continuidad. 
 \\ Artículo Original. So called athletic identity, incompatible with reality: Static identity structure, status transitions and health behaviour dynamics in student athletes. Vol. 7, n. ${ }^{\circ} 1$; p. 67-90, enero 2021. A Coruña. España ISSN 2386-8333
}

\section{Palabras Clave}

Comportamiento de salud; estudiantes deportistas; identidad atlética; transiciones.

\begin{abstract}
The aim of the present study is to examine the athletic identity, status transitions and healthrelated behavioral dynamics of student athletes. Descriptive survey model was used and 398 individuals participated in the present study. Data was collected by Athletic Identity Measurement Scale (AIMS), information form, ranking and closed-ended qualitative questions. According to findings, it was found that the students' downright transitions increased in processes. On the contrary, ANOVA analyses show no differences in athletic identity scores according to grade levels ( $p>.05)$. An increase was seen in maladaptive health behaviors $(p<.05)$. Additionally, maladaptive health behaviors increase after sport termination and beginning of university. It was concluded as a result of the study that individuals' acceptance of athletic identity becomes continuous in spite of the changes in their sport participation status; however, health behaviors are not compatible with the continuity of athletic identity.
\end{abstract}

\section{Keywords}

Athletic identity; student athletes; transitions; health behaviour.

\section{Introduction}

\section{An authentic population: Student athletes}

Student athletes are a social subgroup who are raised with the influence of different environmental conditions and have authentic developmental patterns as a result of their intense experiences of sport participation (Jolly, 2008). Although scientific findings suggest that sport positively affect individuals' socio-psychological development, besides, student athletes may follow a negative course since their participation in sport mainly seeks intensive competition and performance (Merkel, 2013). Branching out in sports and performanceoriented activities occurring in early adolescence, conflicts occurs between experiences in sport and other development areas. During this period, challenges are faced in order to attain a balance within the sport, school and social life (Gomez, Bradley \& Convey, 2018; Stambulova, Engström, Franck, Linnér \& Lindahl, 2015). In addition to sporting achievement, multidimensional expectations also included in the academic achievement dimension may put pressure on student athletes (Cosh \& Tully, 2014). Moreover, the busy 


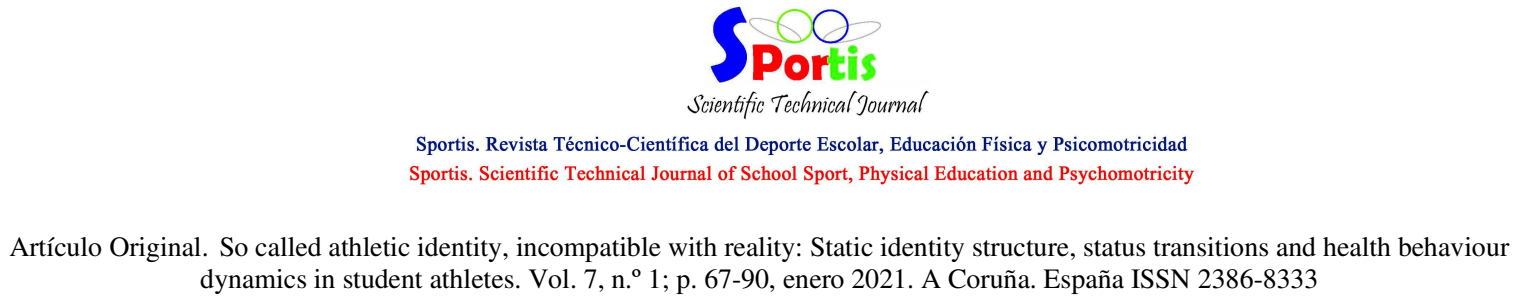

pace due to the sport life (trainings, matches, travels etc.) may restricts the actions intended for the realization of school responsibilities (Jolly, 2008). Decreases in academic performance accompanied by such factors as fatigue, sleep deprivation and stress occurring as a result of this busy life pace may isolate students from activities in school and social life (Sutcliffe \& Greenberger, 2020; Mateu et al., 2020). In addition, because of some negative risk factors like injury, overtraining, sleep disorders, low performance and insufficient income (Xanthopoulos, Benton, Lewis Case, 2020), student athletes' career may come to an end and negative career transitions may be experienced. Alternative opportunities may become limited for student athletes as a result neglecting different developmental experiences after transitions or termination (Brown, Glastetter-Fender \& Shelton, 2000). Studies in the recent literature (Jewett, Kerr \& Tamminen, 2019; Linner, Stambulova, Storm, Kuettel \& Henriksen, 2020; Palermo, Choquette, Ahlich \& Rancourt, 2020; Shriver, Reifsteck, \& Brooks, 2019; Van Rens, Ashley \& Steele, 2019) focused on university level while investigating student athletes, career transitions and their psychological conditions since transition from secondary school to university is an important period for student athletes as they intensively experience dual career challenges and transitions in this period (Mateu et al., 2020). Considering all these facts, psycho-social conditions caused by the life style showing duality between academic, social and sport life make student athletes an more authentic social sub-group than their nonathlete peers.

\section{Identity foreclosure in student athletes}

The risks carried by student athletes during their development period are directly connected with their unidirectional experiences, negligence of exploring other areas and identifying themselves as athletes only. In this regard, many studies report the emergence of identity foreclosure in student athletes due to the restricted exploration and intensive commitment (Brewer \& Petitpas, 2017; Linnemeyer \& Brown, 2010; Murphy, Petitpas \& Brewer, 1996). Identity foreclosure is the identity type in which the individual has a low level of exploration (searching for options) and high level of commitment (Brewer \& Petitpas, 2017). In this regard, high commitment to sporting experiences in the face of low exploration activities plays an important role in emergence of identity foreclosure in student athletes. 


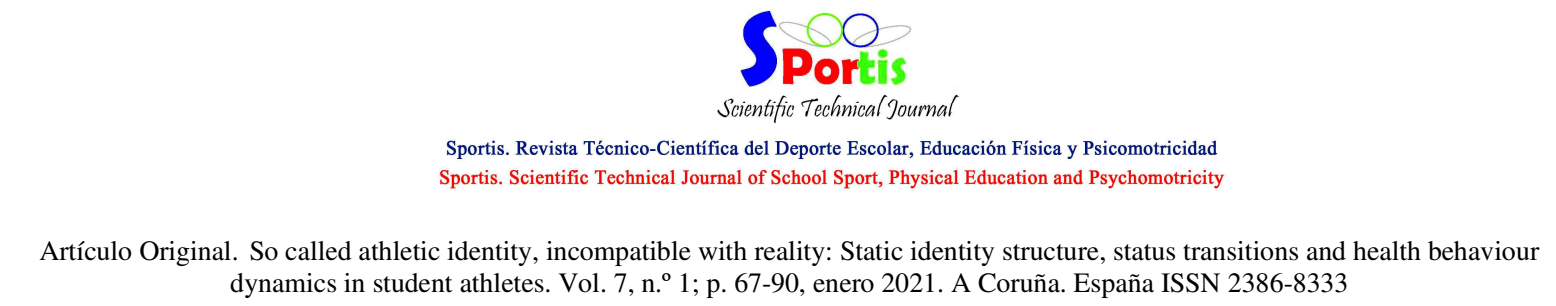

Educational, scientific and sport circles needs to support student athletes with psychopedagogical approach in order to integrate their life skills and sport skills in multiple directions and prevent unilateral identity development (Maulini, Palma \& Ascione, 2020).

In retrospective study conducted by Houle, Brewer and Kluck (2010), identity scores of athletes were seen to increase between 10 and 15 years while they remained stable in the 15-22 years period. The same study reports that identity scores of individuals that terminated sports decreased; however, they kept remaining higher than individuals with no sporting activity (Houle, et al., 2010). Brewer, Van Raalte \& Linder (1993) stated that athletic identity scores decreased with age. Despite these studies, there is a limited number of studies examining identity development of student athletes with a process-oriented perspective. Career transitions, conflicts between school and sporting life, roles and relations in the social environment are all critical components of psycho-social development that can change in process (Menke \& Germany, 2019; Stambulova \& Wylleman, 2019; Sutcliffe \& Greenberger, 2020). As a result of any change that occur in these components, not only could student athletes be exposed to various dynamics, but they may also encounter conflicts concerning identity and behavioral arrangements.

\section{Health related behavioral tendencies in athletes}

When athletes terminate sport, they may have different transitions to new life as positive, neutral and negative (Tracey \& Elcombe, 2004). While individual gives up sport on his/her own, transition occurs in the positive direction (Webb, Nasco, Riley \& Headrick, 1998), in cases when career expectations are not met like in the case of an injury or not to be selected for team, transition occurs in negative direction (Brewer et al., 1993). Intensive sport participation for performance purposes may pose certain risks in student athletes in terms of health related behaviour. These risks, coming out particularly in negative transitions, include such negative factors as physical ailments, injury, stress and depression, unhealthy nutrition, smoking and alcohol consumption (Buckley, Hall, Lassemillante, Ackerman \& Belski, 2019; Palermo, Choquette, Ahlich, \& Rancourt, 2020; Shriver, Reifsteck, \& Brooks, 2019). When performance athletes terminate, their transference into life-long physical activity is limited too (Reifsteck, Gill \& Brooks, 2013; Simon \& Docherty, 2017). Beside, Exercise related identity Para citar este artículo utilice la siguiente referencia: Berkcan, B.; Kiremitci, O. (2021). So called athletic identity, incompatible with reality: Static identity structure, status transitions and health behaviour dynamics in student athletes. Sportis Sci J, 7 (1), 67-90. https://doi.org/10.17979/sportis.2021.7.1.6918 http://revistas.udc.es/ 
acquisition has a more positive effect on life-long physical activity. Additionally, both exercising and athletic identity brings out the most positive result in transition to life-long physical activity (Reifsteck, Gill \& Labban, 2016).
\end{abstract}

\title{
Research Problem and Aim
}

Identity development specified by previous studies, sport participation transitions and the multi-directional changes in health behaviour tendencies make our questions stronger concerning dynamic development processes in student athletes. Researches in the related literature above separately investigated identity foreclosure, transitions and health behaviours. Additionally, as it is seen, limited number of researches investigated process orientations (age, time, period or grade levels etc.) and focused on possible changes or stabilities. This research originally aimed to investigate athletic identity, transitions and health behaviours in university students considering process orientations by considering grade level as student athletes' years spent at university are part of an important developmental period. Considering the aim, main research questions of current study are determined as follows:

1. How sport participation status of student athletes are formed considering their previous and their current states?

2. How status transitions in sport participation vary considering grade level?

3. Does athletic identity level of student athletes differ according to grade level?

4. Do health behaviours of student athletes differ according to grade level?

5. How do student athletes perceive changes of healthy life behaviours considering university life and sport termination?

\section{Method}

\section{Study model and participants}

Descriptive survey model used in the present study. Data collection process was conducted using cross-sectional design. Employing criterion sampling, participants' characteristics were identified prior to the study. Below is the criteria concerning the characteristics of the individuals included in the study;

(1) Inclusion of 1st, 2nd, 3rd and 4th grade level students into the study with an equal 
Artículo Original. So called athletic identity, incompatible with reality: Static identity structure, status transitions and health behaviour dynamics in student athletes. Vol. 7, n. ${ }^{\circ} 1 ;$ p. 67-90, enero 2021. A Coruña. España ISSN 2386-8333

distribution in an optimal level.

(2) Individuals receiving higher education and actively continuing their educational activities as a student athlete.

(3) Individuals participating in sports or having backgrounds in sport participation and those with no participation in sports,

(4) Individuals showing typical characteristics and variety in terms of the types of sport participation (professional, amateur, physical activity and exercise, non-participation)

Individuals failing to meet any of the given criteria were not included into the study. The study was participated by 398 students; 115 first year (28,89\%), 108 second year (27,14\%), 102 third year $(25,63 \%)$ and 73 fourth year (18,34\%) students. As for the gender variable, the participants were distributed as 231 (58,04\%) males and 167 females $(41,96 \%)$. Participants' age ranged between 18 and 25 ages. Mean age was calculated as $21.45 \pm 2.28$.
\end{abstract}

\title{
Data collection tools
}

The data collection instruments used in the present study are consisted by 3 categories as Athletic Identity Measurement Scale (AIMS), demographic information form and quantitative-qualitative questions.

\section{Athletic identity measurement scale}

AIMS aiming to measure degrees that individuals identify themselves as an athlete role. The scale is consisted by items which measures commitment dimension of identity in sport and degree of athletic identity foreclosure. In this regard, the scale provides measurement and evaluation of identity foreclosure in a sport specific way rather than general psycho-social identity development measurement tools that do not include sport specific items (Brewer \& Petitpas, 2017). Therefore, AIMS is the most commonly used measurement tool (Ronkainen, Kavoura \& Ryba, 2016) by researchers who investigate athletic identity, dual career, career transitions and academic issues etc. in student athletes. Although, AIMS was firstly referred in 1990's (Brewer et al.,1993), the scale has been kept up to date and continued to be relevant in scientific studies as there were still many researches in recent literature which used AIMS as a measurement tool (Foster \& Homl, 2017; Reifsteck et al., 2016; Rongen, McKenna, 


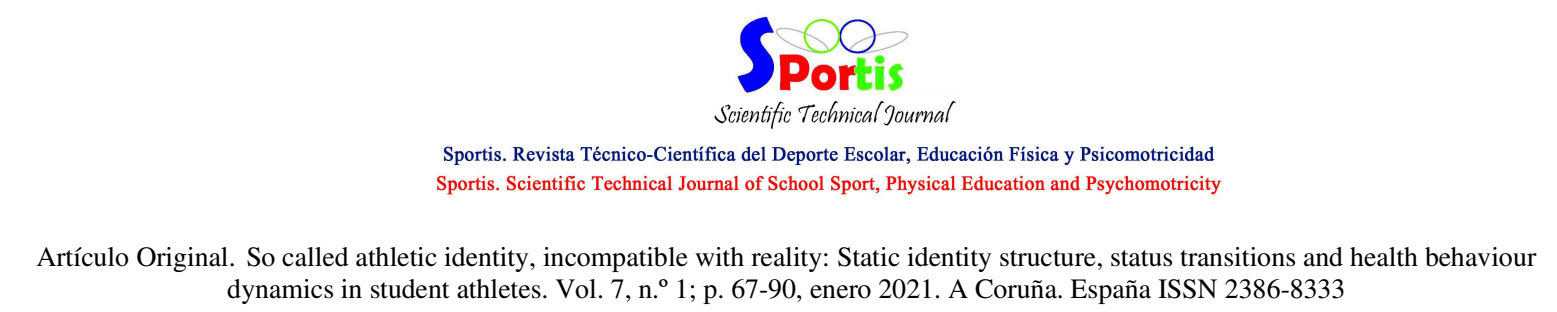

Cobley, Tee \& Till, 2020; Walton, Baranoff, Gilbert \& Kirby, 2020).

AIMS was developed by Brewer and Cornelius (2001), and the Turkish adaptation study was conducted by Öztürk and Koca (2013). The scale consisted by 7 items and all items are 7-point Likert type scale ( $1=$ Strongly disagree, $7=$ Strongly Agree). Score 1 shows low level of commitment in athletic identity while score 7 shows high level of commitment in athletic identity. The internal consistency coefficient was calculated as .81 for athletic identity as single dimension (Öztürk \& Koca, 2013).

\section{Information form}

The information form was designed to obtain information about the participants' age, gender, department and grade. The data obtained from the information form made it possible to get an optimal level of equality in the distribution among grade levels and to examine the participating individuals' distribution by the demographic characteristics.

\section{Ranking questions and closed ended qualitative questions}

Structured questions in quantitative and qualitative type were prepared by researchers in order to determine the participants' transitions in sport participation status (previous and present state), their physical activity frequencies, smoking and alcohol consumption frequencies and habits. Questions also includes how student athletes perceive changes in health behaviours during university life and after termination of sport.

Questions intended for determining sport participation status and transitions were consisted by multiple choice questions ( 2 questions):

Question 1: Current sport participation status of the participant "How could you describe your current status of participation in sport activities?'’Multiple choices are as follows which represents different participation status:

a) I am a professional athlete (Competing and training for income, competition and achievement purposes)

b) I am an amateur athlete (Voluntarily participating in a sports club)

c) I do activities like training, exercise, fitness etc. regularly.

d) I am not engaged in regular sports or physical activity.

Para citar este artículo utilice la siguiente referencia: Berkcan, B.; Kiremitci, O. (2021). So called athletic identity, incompatible with reality: Static identity structure, status transitions and health behaviour dynamics in student athletes. Sportis Sci J, 7 (1), 67-90. https://doi.org/10.17979/sportis.2021.7.1.6918 http://revistas.udc.es/ 


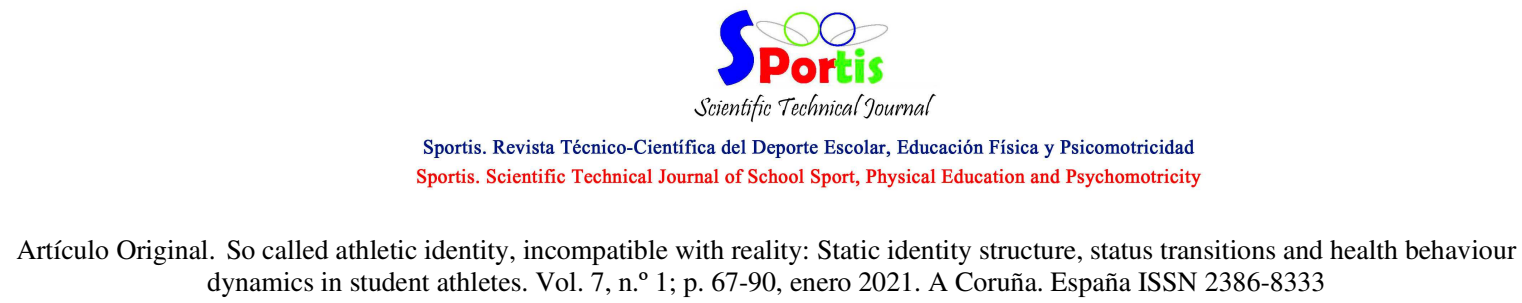

Question 2: Previous sport participation status of the participant "If different from current, what was your previous sport participation status in sport activities?' Multiple choices are the same with the first question (professional athlete, amateur athlete, regular physical activity and non-participant).

Based on two questions above, three different features of transition were defined as stable, downright and upright transitions according to previous and current sport participation statuses. Status order was described from the lowest step to highest as follow: non-participant, physical activity, amateur athlete and professional athlete. Transition from lower to upper step was described as upright transition, from upper to lower was described as downright transition and if status did not differ from previous to current situation it was described as stable position.

The ranking questions which aim to determine frequency of physical activity, alcohol consumption and smoking (3 questions):

Question 1: How many times a week do you get physical activity or exercise on average? (competitions, training, physical activity, exercise, fitness etc.)

Never....1 day ....2 days.....3 days.....4 days.....5 days.....6 days.....7 days.....

Question 2: How do you describe your smoking frequency considering the scale below?

Never.....1....2....3...4....5....6.....7....Very Often

Question 3: How do you describe your alcohol consumption frequency considering the scale below?

Never...... $1 \ldots . .2 \ldots . .3 \ldots . . . . . .5 \ldots . .6 \ldots . . . . .$. Very Often

Closed-ended qualitative question was prepared to determine student athletes' smoking and alcohol consumption conditions, their perceptions of effect of university life and sport termination on smoking and alcohol consumption (8 Questions). Firstly, we asked the participant whether he/she smoke or not, if his/her response is yes, we continued to ask other questions about smoking frequency at university whether increased or not, smoking or not when they were an athlete and smoking less or not when they were an athlete. The same questions were repeated for alcohol comsumption. In this regard, we asked the participant whether he/she consume alcohol or not, if his/response is yes, we continued to ask other Para citar este artículo utilice la siguiente referencia: Berkcan, B.; Kiremitci, O. (2021). So called athletic identity, incompatible with reality: Static identity structure, status transitions and health behaviour dynamics in student athletes. Sportis Sci J, 7 (1), 67-90. https://doi.org/10.17979/sportis.2021.7.1.6918 http://revistas.udc.es/ 
questions about alcohol consumption frequency at university whether increased or not, consuming alcohol or not when they were an athlete and consuming less alcohol or not when they were an athlete.
\end{abstract}

\title{
Procedure
}

After taking permission to use Athletic Identity Scale from corresponding author, application was made to Ege University Scientific Research and Publication Ethics Committee and scientific research approval was received from ethical committee (Protocol no: 376). Later, a data collection calendar was developed for the meetings to be held with students. Data collection process was realized in classroom environment at Ege University Faculty of Sport Sciences. In group meetings held in the classroom environment, students were informed about instructions of the research and data collection process. In each meeting section, researchers took care of following same instruction order by providing a checklist. All participants have read and signed consent forms prior to the study. Regardless of time, data collection were completed when students finished answering data collection form.

\section{Data analyses}

In order to perform a reliable coding, the data collected from participants were organized through number order. Then, data coding and analyses was performed on SPSS 24.0. In the first step, 27 participant were excluded from the study for involving missing information, contradictory expressions and outliers (Field, 2009). Analysis were performed by 398 individuals. Normality test were performed prior to analyses and appearance of histogram graphs and skewness kurtosis values considered (Field, 2009). It was observed that data distributed as normal. One-way ANOVA is conducted to compare means and categorical groups. Significance value for ANOVA analyses were considered $p<.05$ and $p<.01$ in the evaluation of analyses. Descriptive statistics was performed to calculate means and percentages in status transitions and health behaviours. Cohen (1988) effect size guidelines were also followed to evaluate mean difference levels (Small=0.2-0.49, medium=0.5-.0.79, large $=0.8$ and more). 
Artículo Original. So called athletic identity, incompatible with reality: Static identity structure, status transitions and health behaviour dynamics in student athletes. Vol. 7, n. ${ }^{\circ} 1$; p. 67-90, enero 2021. A Coruña. España ISSN 2386-8333

\section{Results}

It was seen that $45,98 \%$ of the individuals $(n=183)$ used to be professional athletes, $41,96 \%$ were amateur athletes $(n=167)$ and $10,3 \%$ physical activities and exercisers $(n=41)$ and $1,76 \%$ did not participate in sports or physical activity $(n=7)$ in previous state. As for the current states, the ratio of professional athletes decreased to $22,61 \%(n=90)$, and amateur athletes to $17,08 \%(n=68)$. While ratio of exercisers regularly increased to $31,16 \%(n=124)$ and of those not participating any activities increased to $29,15 \%(n=116)$ (Figure 1).

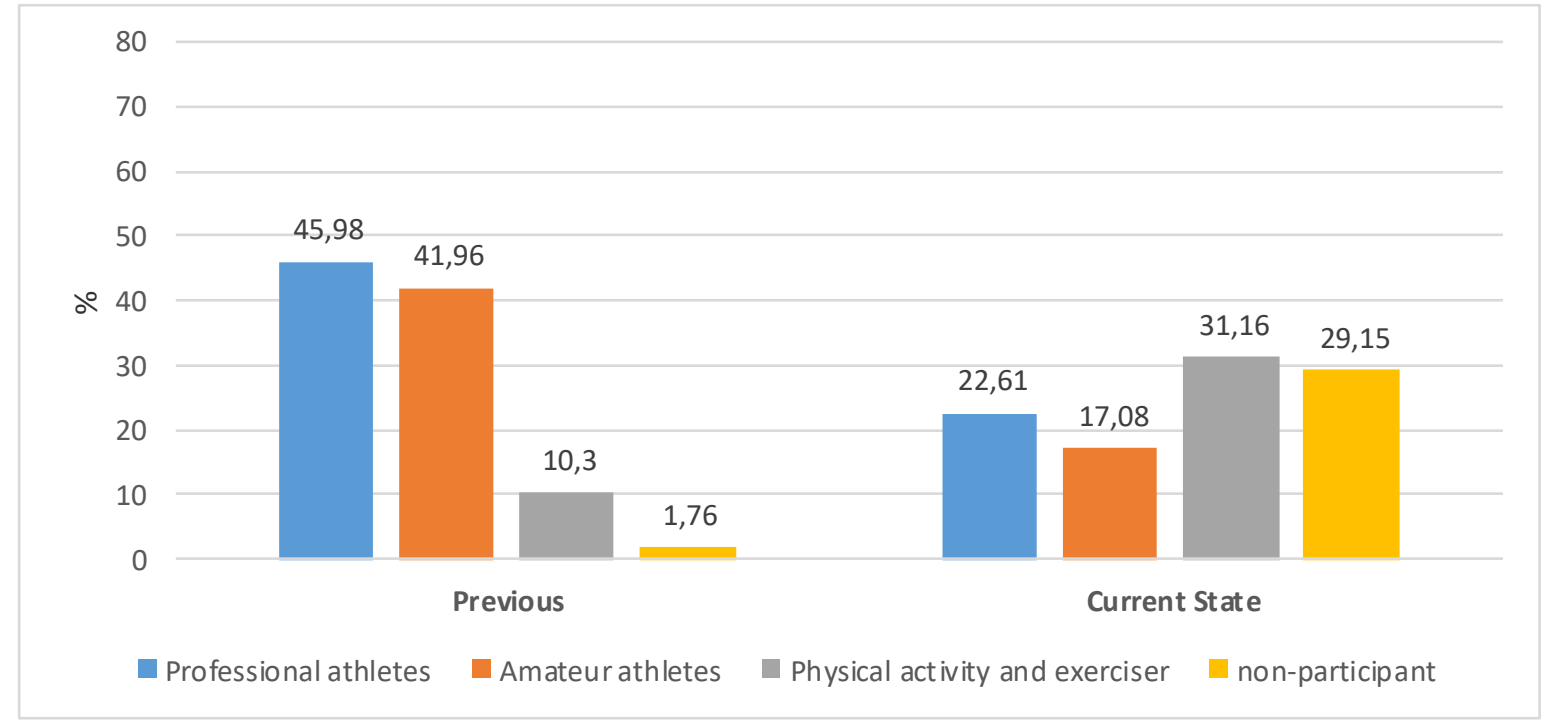

Figure 1. Participants' sport participation statuses according to previous and current states

In Figure 2, it is seen that the ratio of individuals experiencing downright transition in year one is $40 \%$ while it is $71,2 \%$ in year four. On the other hand, the ratio of individuals maintaining their previous participation levels (stable) fell from $58,3 \%$ in year one to $28,8 \%$ in year four. There are only 4 individuals who experienced upright transition, and 2 of them in year one $(1,7 \%), 2$ of them in year two $(1,7 \%)$ (Figure 2$)$. 
Artículo Original. So called athletic identity, incompatible with reality: Static identity structure, status transitions and health behaviour dynamics in student athletes. Vol. 7, n. ${ }^{\circ} 1$; p. 67-90, enero 2021. A Coruña. España ISSN 2386-8333

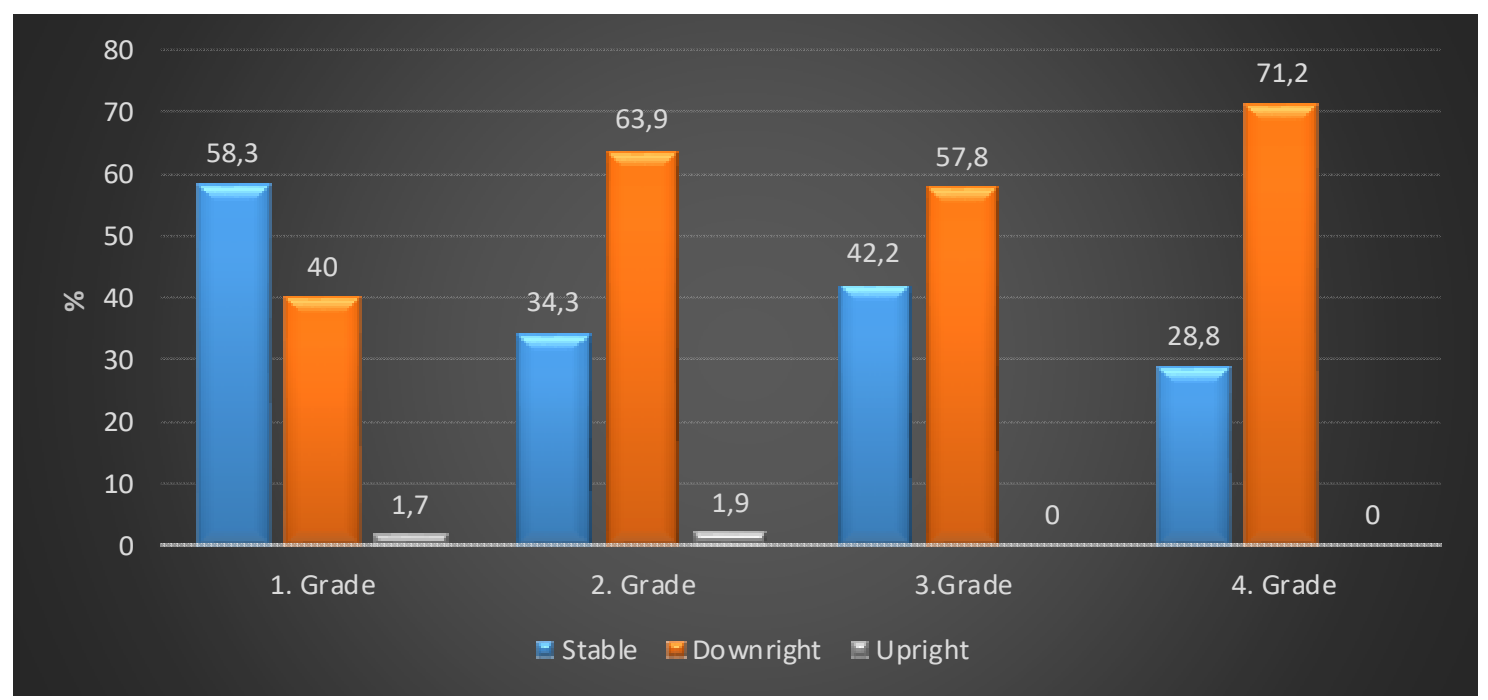

Figure 2. Variance of status transitions in terms of sport participation types by grade level

In order to reveal the differences in the participants' athletic identity means in the process, analysis were made considering the grade level variable and the mean scores were found as 5,75 $\pm 1,13$ for first year students, 5,50 $\pm 1,10$ for second year students, 5,46 $\pm 1,03$ for third year students and 5,37 $\pm 1,10$ for fourth year students. As a result of the ANOVA analysis performed, the mean difference between grade levels was not significant $(\mathrm{F}=2,17 ; \mathrm{p}=$ .91) (Figure 3).

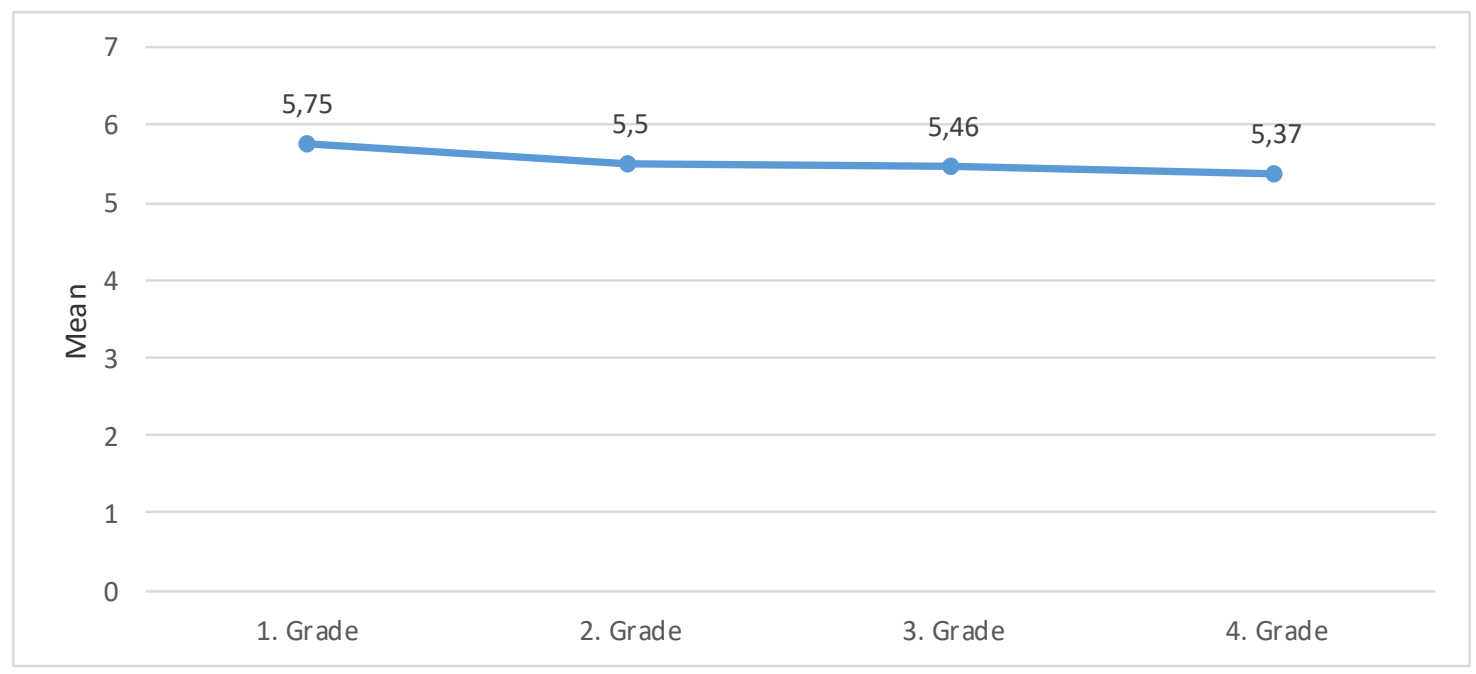

Figure 3. Comparison of athletic identity mean scores by grade level

Para citar este artículo utilice la siguiente referencia: Berkcan, B.; Kiremitci, O. (2021). So called athletic identity, incompatible with reality: Static identity structure, status transitions and health behaviour dynamics in student athletes. Sportis Sci J, 7 (1), 67-90. https://doi.org/10.17979/sportis.2021.7.1.6918 http://revistas.udc.es/ 
Artículo Original. So called athletic identity, incompatible with reality: Static identity structure, status transitions and health behaviour dynamics in student athletes. Vol. 7, n. ${ }^{\circ} 1$; p. 67-90, enero 2021. A Coruña. España ISSN 2386-8333

Table 1. Differences in the athletic' identity scores by sport participation status

\begin{tabular}{|c|c|c|c|c|c|}
\hline Participation Status & Mean & Sd. & F Value & Post-hoc & Cohen (d value) \\
\hline \multirow[t]{2}{*}{ Professional } & 6.23 & .67 & \multirow{7}{*}{$33.47 * *$} & & \\
\hline & & & & $\mathrm{P}>\mathrm{A} * *$ & $\mathrm{P}>\mathrm{A}=.67(\mathrm{M})$ \\
\hline \multirow[t]{2}{*}{ Amateur } & 5.64 & 1.06 & & $\mathrm{P}>\mathrm{E}^{* *}$ & $\mathrm{P}>\mathrm{E}=.74(\mathrm{M})$ \\
\hline & & & & $\mathrm{P}>\mathrm{N}^{* *}$ & $\mathrm{P}>\mathrm{N}=1.46(\mathrm{H})$ \\
\hline \multirow[t]{2}{*}{ Exercise } & 5.61 & .96 & & $\mathrm{~A}>\mathrm{N}^{* *}$ & $\mathrm{~A}>\mathrm{N}=.71(\mathrm{M})$ \\
\hline & & & & $\mathrm{E}>\mathrm{N} * *$ & $\mathrm{E}>\mathrm{N}=.71(\mathrm{M})$ \\
\hline Non-participant & 4.86 & 1.15 & & & \\
\hline
\end{tabular}

p>0.01** (Abbreviations: P:Professional, A: Amateur, E= Exercise and Physical Activity, N: Nonparticipant, L= Low, M= Middle, $\mathrm{H}=$ High (Cohen, 1988).

A significant difference was found between the participants' athletic identity scores in terms of their sport participation statuses $(\mathrm{F}=33.47 * *, \mathrm{p}=0.00)$. Accordingly, identity scores of professional athletes are significantly higher than amateur athletes, exercisers and nonparticipants. In addition, identity scores of amateur athletes and exercisers are significantly higher than non-participant (Table 1). 
Artículo Original. So called athletic identity, incompatible with reality: Static identity structure, status transitions and health behaviour dynamics in student athletes. Vol. 7, n. ${ }^{\circ} 1$; p. 67-90, enero 2021. A Coruña. España ISSN 2386-8333

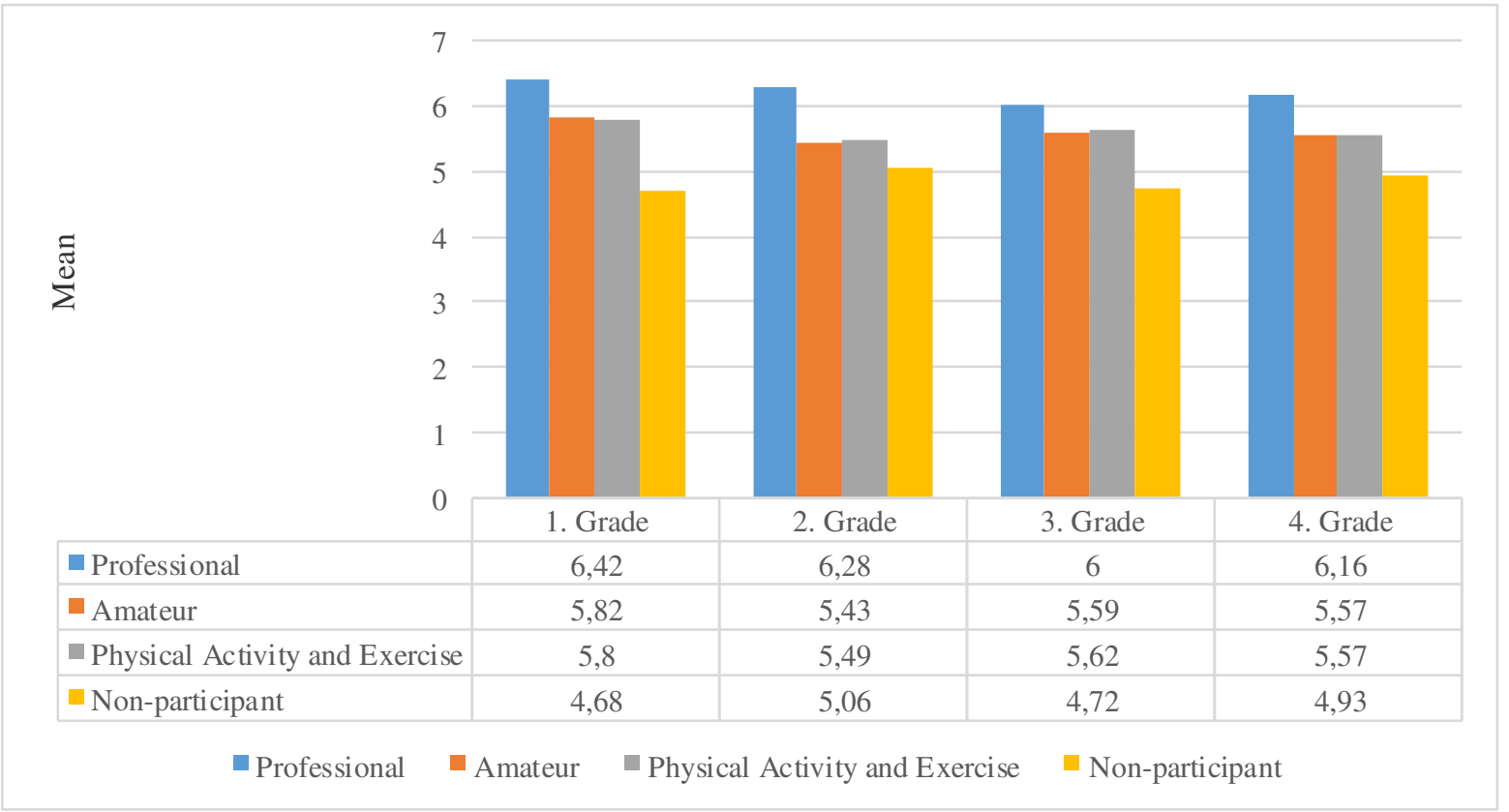

Figure 4. Identity scores according to their sport participation statuses and grade level

No difference was found in athletic identity level within the same status according to grade level (Professional Athlete: $\mathrm{F}=2.07$, sig= .11; Amateur Athlete: $\mathrm{F}=.57$; sig= .64, Exercise and Physical Activity: $\mathrm{F}=.65$, sig= .59; No participation: $\mathrm{F}=.69$, sig= .56) (Figure 4).

Examining the participants' mean scores by weekly physical activity frequencies, it is seen that participation in physical activity decreases as grade level increases $\left(1^{\text {st }}\right.$ Year: 4,46 $\pm 1,58 ; 2^{\text {nd }}$ Year: $4,09 \pm 1,59 ; 3^{\text {rd }}$ Year: $4,07 \pm 1,72 ; 4^{\text {th }}$ Year: $\left.3,47 \pm 1,56\right)$ and that there is a statistically significant difference between the mean scores of first and fourth year students $(\mathrm{F}=5,64 ; \mathrm{p}=.001)$. The difference has a medium effect size $(\mathrm{d}=.63)$. Smoking frequency differentiate from the first year towards the third year, a statistically significant difference was observed between the means of $1^{\text {st }}(3,78 \pm 1,83)$ and $3^{\text {rd }}(5,05 \pm 1,72)$ year students $(F=2,81$; $\mathrm{p}=.04)$. The difference has a medium effect size $(\mathrm{d}=.72)$. Although a relative increase is seen in alcohol consumption frequency from the $1^{\text {st }}$ year towards the $4^{\text {th }}$ year, ANOVA analysis shows no difference between means $(\mathrm{F}=1,14 ; \mathrm{p}=.33)$ (Figure 5). 
Artículo Original. So called athletic identity, incompatible with reality: Static identity structure, status transitions and health behaviour dynamics in student athletes. Vol. 7, n. ${ }^{\circ} 1$; p. 67-90, enero 2021. A Coruña. España ISSN 2386-8333

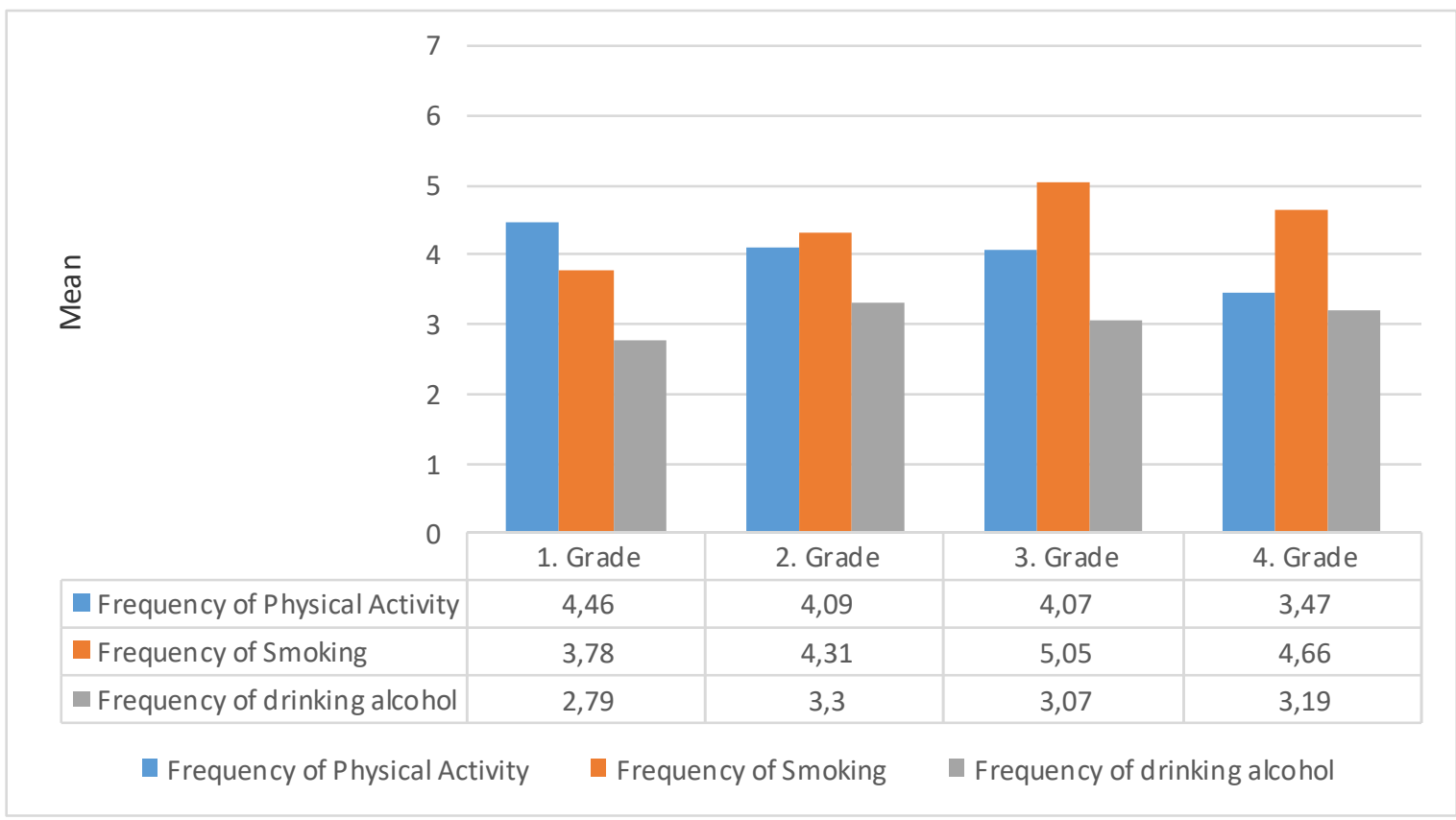

Figure 5. Physical activity, smoking and alcohol consumption frequencies by grade level

Findings show that $69,6 \%$ stated their smoking frequency increased at university. There is a remarkable ratio of those responding as "I didn't use to smoke when I was an athlete " (46,3\%) and as "I used to smoke less when I was an athlete" $(\% 64,3)$. As for alcohol consumption, 45,3\% of the participants stated that their alcohol consumption frequency increased at university, 35,3\% expressed that "I did not use to consume alcohol when I was an athlete" and 55\% responded that "I used to consume less alcohol when I was an athlete (Figure 6). 
Artículo Original. So called athletic identity, incompatible with reality: Static identity structure, status transitions and health behaviour dynamics in student athletes. Vol. 7, n. ${ }^{\circ} 1$; p. 67-90, enero 2021. A Coruña. España ISSN 2386-8333

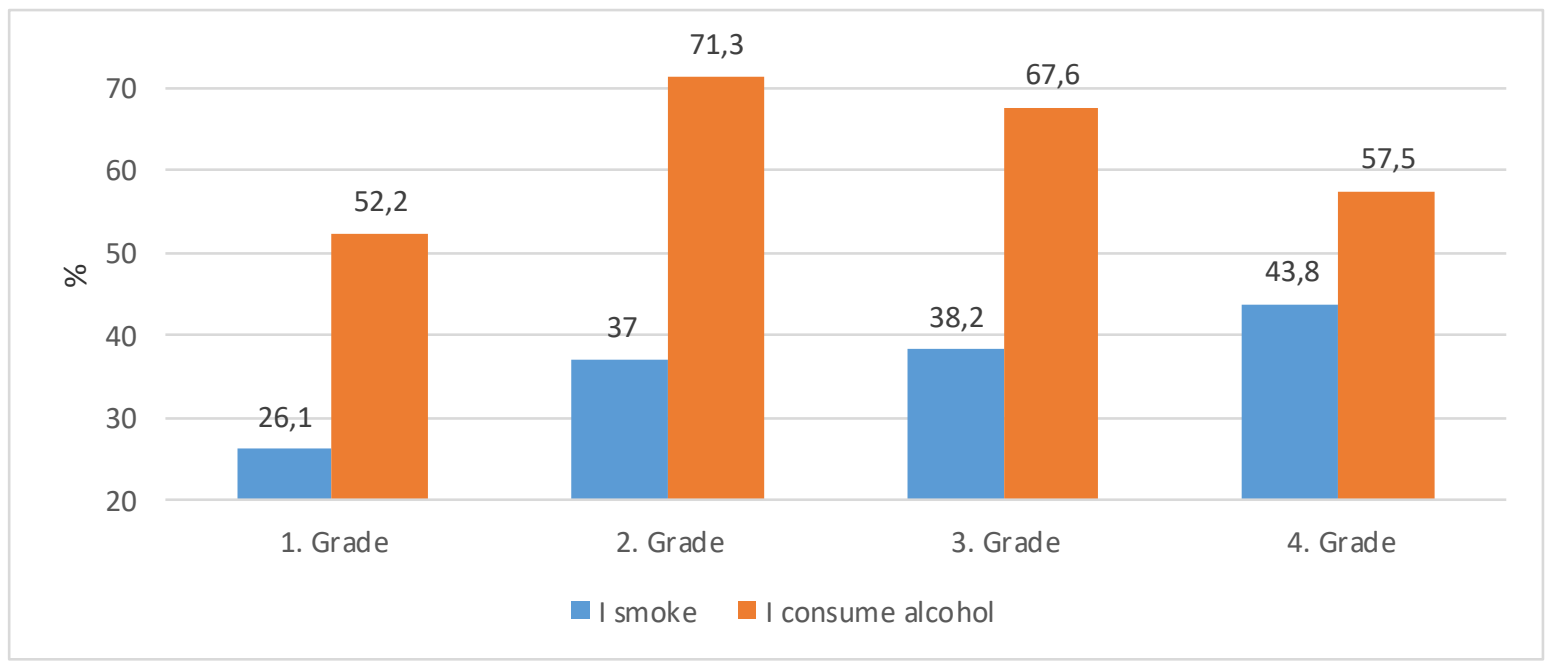

Figure 6. Responses to the qualitative questions about smoking and alcohol consumption

It was found that $26,1 \%$ of the first year students, $37 \%$ of the second year students, $38,2 \%$ of the third and $43,8 \%$ of the fourth year students are smokers. Alcohol consumption rates of student athletes are as follows: $52,2 \%$ in the first year, $71,3 \%$ in the second year, $67,6 \%$ in the third year and $57.5 \%$ in the fourth year (Figure 7).

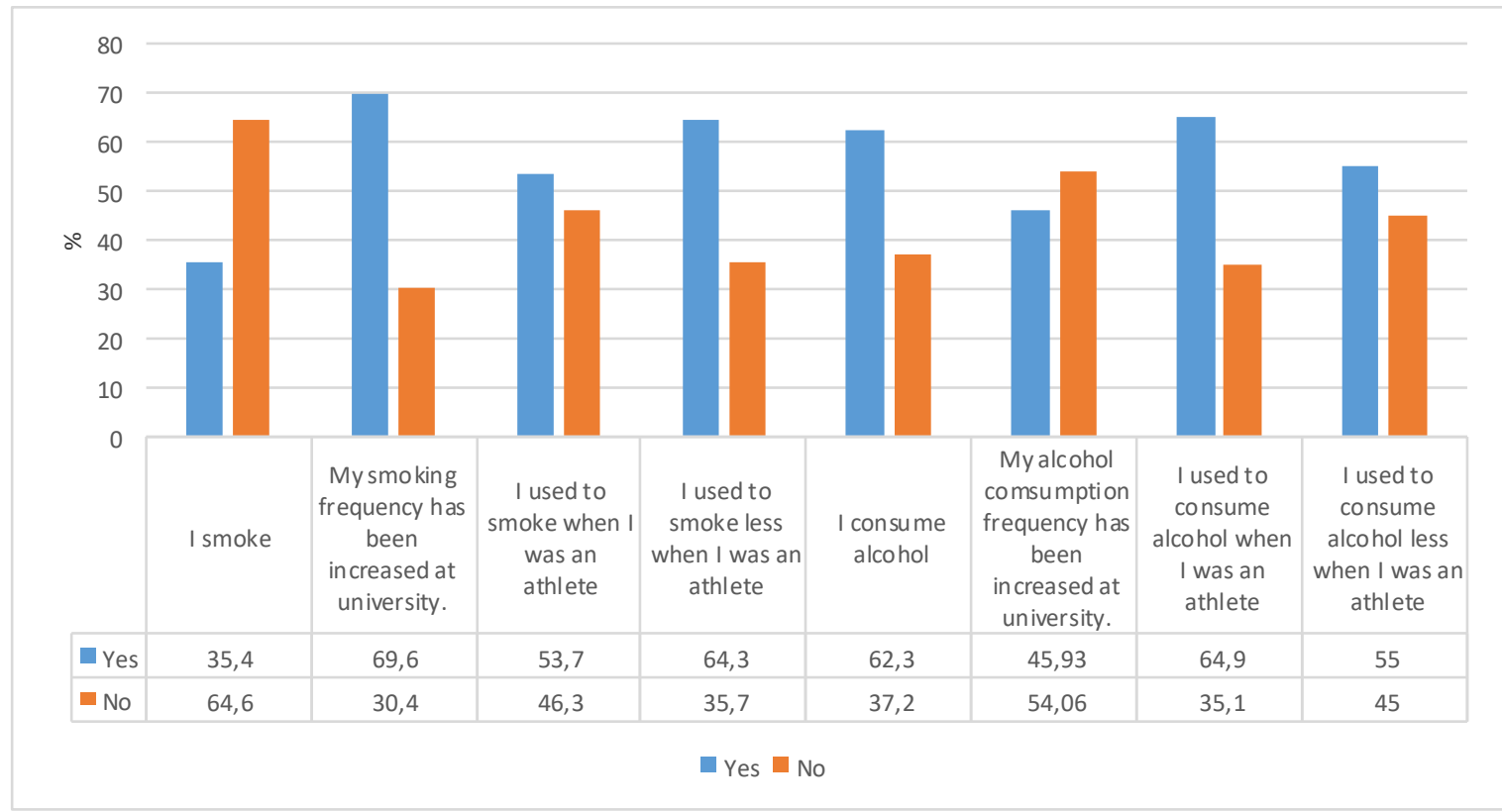

Figure 7. Distribution of smoking and alcohol consumption rates by grade level

Para citar este artículo utilice la siguiente referencia: Berkcan, B.; Kiremitci, O. (2021). So called athletic identity, incompatible with reality: Static identity structure, status transitions and health behaviour dynamics in student athletes. Sportis Sci J, 7 (1), 67-90. https://doi.org/10.17979/sportis.2021.7.1.6918 http://revistas.udc.es/ 


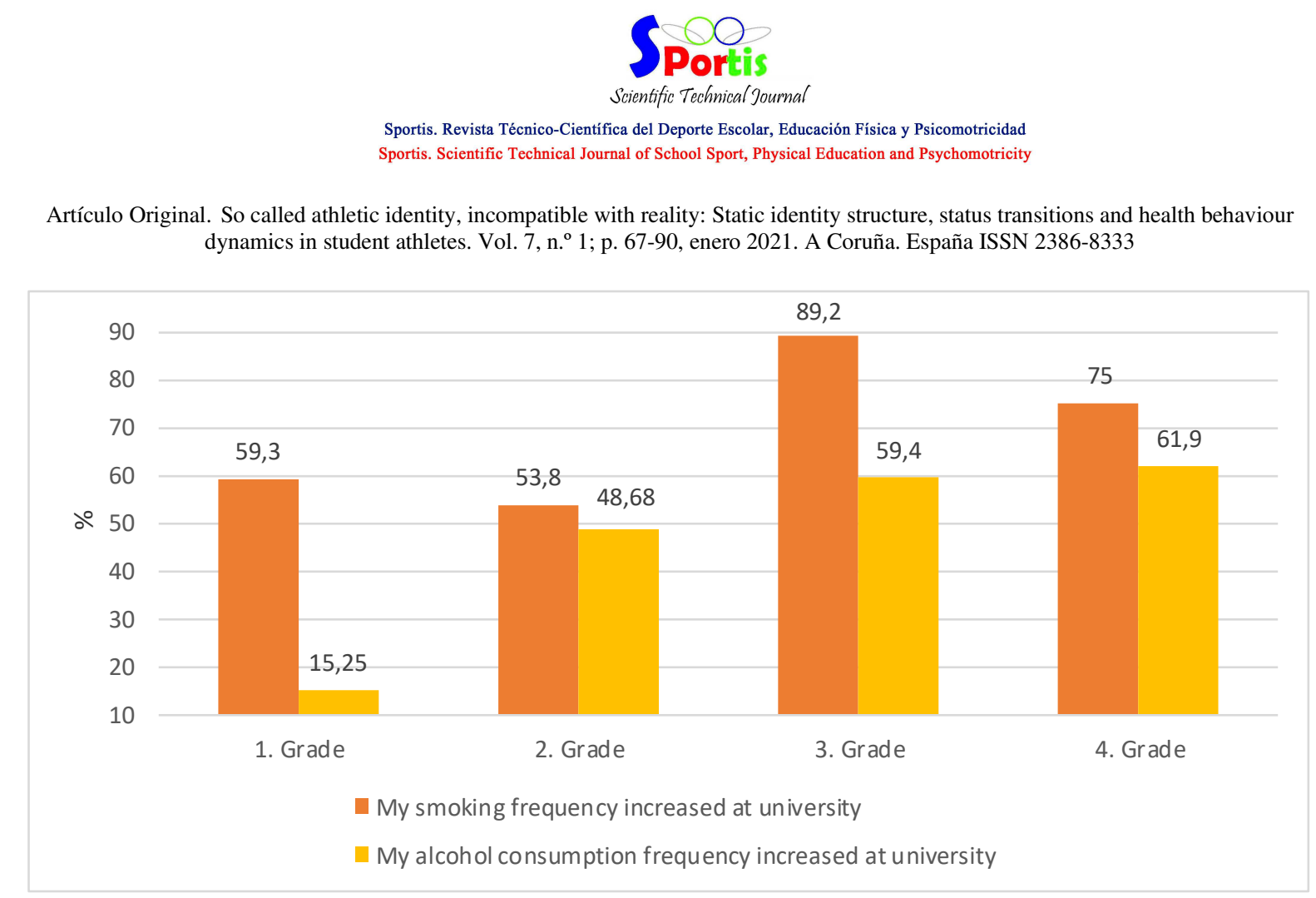

Figure 8. Variance of responses to questions about smoking and alcohol consumption

Individuals responding as "my smoking frequency increased at university" hold up $15,25 \%$ in the first year, $46,28 \%$ in the second year, $59,24 \%$ in the third year and $61,9 \%$ in the fourth year. On the other hand, those who responded as "my alcohol consumption frequency increased at university" have a share of 59,3\% in the first year, 53,8\% in the second year, $89,2 \%$ in the third year and $75 \%$ in the fourth year (Figure 8 ).

\section{Discussion and Conclusions}

Studies reported that identity scores of athletes tend to decrease in direct proportion to age and time (Brewer, et al., 1993; Miller \& Kerr, 2003), and that identity scores also go down after the termination of sport (Houle, et al., 2010; Grove, Fish \& Ekiund, 2004; Shachar, Brewer, Cornelius \& Petitpas, 2004). Similarly, other studies (Houle, et al., 2010; Grove et al., 2004; Shachar, et al., 2004) reported that athletic identity scores are observed to have decreased notably after experiencing downward transition. In retrospective study conducted by Houle, et al. (2010), it was seen that identity scores of active athletes increased at ages 10-15; whereas they became stable between ages of 15 and 22. It is stated in the same study that a linear decrease occurred over time in identity scores of individuals terminated sport. However, despite this linear decrease, identity scores of the individuals who terminated sports remain higher than the scores of non-athletes in that study. In our study, we did not 
observe specific change in athletic identity scores of participants according to grade level (Figure 3), although their athletic identity scores differ according to participation status that supports related literature above (Table 1), however there was still no difference of athletic identity level within same statuses according to grade level (Figure 4). Therefore, we found significantly different means in athletic identity scores according to participant status that supports related literature. However, our results are different from literature in point of process evaluation that reveals athletic identity scores do not change according to grade level. It may be considered that athletic identity differ according to status position, but not change in process (grade level). On the other hand, our results should be discussed by replication studies conducted by longitudinal design.
\end{abstract}

Brewer and Petitpas (2017) stated, identity foreclosure mostly seen in emerging adulthood phase. Our study also focused on individuals aged between 18-25 period. This period which follows adolescence is called emerging adulthood and described as final stage of identity development (Arnett, 2007). Emerging adulthood is considered as the period when individual has many self-exploring experiences and crises, critical decisions about life and is stuck between adolescence and adulthood (Arnett, 2007). In this regard, experience of many contradictions in identity and healthy life behaviors of student athletes may be occurred in emerging adulthood. Maintenance of identity and increase in maladaptive behaviors is a finding that is worth attention in emerging adulthood phase in our study which is a sign of identity foreclosure and additionally the contradicted structure between identity structure and behaviors.

In our study, despite the static structure of athletic identity, it was seen that their health behavioral characteristics were not compatible with continuing identity. Reifsteck et al. (2016) reported that former athletes had difficulty in lifelong participation to physical activity. Similarly, Reifsteck et al. (2013) found that athletic identity scores were higher in former college athletes, but they did not differ from non-sporting individuals in terms of lifelong physical activity. Moreover, physical activity level of former athletes is stated to decrease after graduation from university in comparison with non-sporting individuals. Researchers associated this decrease in physical activity levels with termination of sport (Reifsteck, et al., Para citar este artículo utilice la siguiente referencia: Berkcan, B.; Kiremitci, O. (2021). So called athletic identity, incompatible with reality: Static identity structure, status transitions and health behaviour dynamics in student athletes. Sportis Sci J, 7 (1), 67-90. https://doi.org/10.17979/sportis.2021.7.1.6918 http://revistas.udc.es/ 


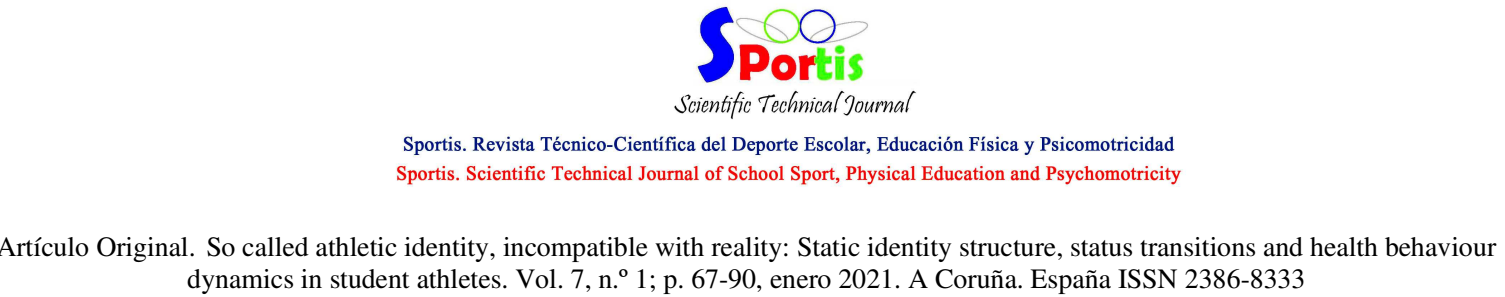

2013). In the study carried out by Reifsteck, et al. (2016) examined effect of athletic and exercise identity types on life-long participation in physical activity. Accordingly, acquiring exercise identity plays a more significant role than athletic identity in life-long physical activity participation. While athletic identity is a type of identity that develops through competition and performance; exercise identity is formed by self-perceptions concerning participation in physical activity on voluntary basis. In this regard, low levels of exercise identity of former athletes decrease their lifelong participation in physical activity, while having high levels in both athletic and exercise identities is the most effective state for increasing lifelong physical activity participation (Reifsteck, et al., 2016). According to Tracey and Elcombe (2004), the fact that individuals participating in elite sports form their sport-related experiences around a utilitarian attitude. Thus, concept of training rather than physical activity is dominant in their sport life may play a role in the limited participation of physical activity after giving up sports. Our study supports studies that reports decreased physical activity in athletes and utilitarian attitudes of student athletes. In addition, individuals' frequent exposure to atypical physical stimuli (high intensity training, use of performance-enhancing substances, injuries, chronic pain, irregular weight gain/loss) may negatively affect participation in physical activity after sport termination (Tracey \& Elcombe, 2004).

Kerr, DeFreese and Marshall (2014) stated that alcohol consumption and unhealthy nutrition behaviors are more frequent in student athletes continuing their careers compared to the general population, in terms of other health-related behaviors; however, they did not differ from general American population. Other studies report an increase in such behaviors as unhealthy nutrition, alcohol consumption and smoking in addition to psychological and physical disorders in athletes after termination sport or goals (Buckley et al., 2019; Çebi, Eliöz, Yamak, Imamoglu \& Aksoy, 2020; Wippert \& Wippert, 2008). Similarly, we found a negative course in terms of health behaviors especially for physical activity and smoking in Turkish student athlete population. It is considered in our results that the maladaptive health behavior accompanying continuing athletic identity may bring about a controversial identity and behavior pattern in student athletes. Likewise, Buckley et al. (2019) suggest that 
Artículo Original. So called athletic identity, incompatible with reality: Static identity structure, status transitions and health behaviour dynamics in student athletes. Vol. 7, n. ${ }^{\circ} 1$; p. 67-90, enero 2021. A Coruña. España ISSN 2386-8333

continuing athletic identity in individuals whose sport careers were terminated causes an increase in maladaptive health behaviors. Our results also support that continuing athletic identity and increase in maladaptive behaviors. It is important to apply policies and programs to support transition experiences of student athletes and improve sport university culture
\end{abstract} (Chin, Johnson, Signer-Kroeker \& Holman, 2020).

In summary, results showed that downward transitions of sport participation status increased in student athletes in general and according to grade level. In addition, it was seen that athletic identity scores of student athletes did not differ according to grade level. Individuals had different levels of identity scores according to sport participation statuses. Maladaptive health behaviors in student athletes tend to be increased according to grade level. University life and termination of sport in particular may seen to be effective on increase of maladaptive health behaviors. It is important to include preventive and supportive practices in issues like career, transitions and healthy lifestyle behaviors.

In conclusion, despite the downward transitions increasing in student athletes' sport participation statuses in process, the athletic identity structure preserved in essence (core) remained so-called. Particularly after career and sporting expectations ended, it is seen that health behaviors were not transferred to life after sport and university life. In other words, it was determined that the individual's athletic identity became static in process; but health related behavioral dynamics were not compatible with this continuity. The present study is concluded with the proposal of a sub-identity type that can be defined as So-called athletic identity in student athletes.

\title{
Limitations
}

The first limitation of the present study is that the process-based evaluations were made considering grade levels. In spite of this limitation, student athletes' years spent at school are part of an important developmental period and process as a reflection of the conflicts in both their sporting and school experiences. As a matter of fact, these individuals experience many conflicts about their psycho-social development in the period during their educational life and many changes in career and sport participation as well as behavioral Para citar este artículo utilice la siguiente referencia: Berkcan, B.; Kiremitci, O. (2021). So called athletic identity, incompatible with reality: Static identity structure, status transitions and health behaviour dynamics in student athletes. Sportis Sci J, 7 (1), 67-90. https://doi.org/10.17979/sportis.2021.7.1.6918 http://revistas.udc.es/ 


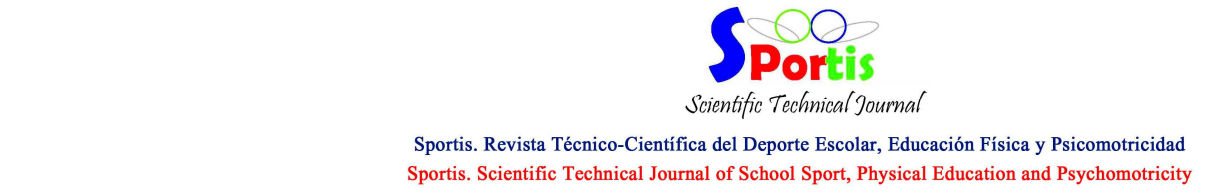

Artículo Original. So called athletic identity, incompatible with reality: Static identity structure, status transitions and health behaviour dynamics in student athletes. Vol. 7, n. ${ }^{\circ} 1$; p. 67-90, enero 2021. A Coruña. España ISSN 2386-8333

arrangements take place in this process. On the other hand, in order to examine the "So-called Athletic Identity" in depth, studies should also be conducted paying attention to age variable. Quantitative and qualitative questions may be broaden in future studies while evaluating physical activity, alcohol consumption and smoking by specifying amount and type. Comparison between past (athletic experience) and current situation may be done by open ended questions which deeply investigate multiple status transitions from past to present and maladaptive health behaviours.

The process-based evaluations in the present study were performed with students in different grade levels using cross-sectional design. For future studies, process-based examinations are recommended to consider longitudinal and retrospective designs. On the other hand, we included individuals of similar characteristics by using criterion sampling that may decrease the limitations of the cross-sectional design. Another issue to be evaluated by future studies is the use of qualitative approaches and analyses at individual levels. The Socalled Athletic Identity may come up as a sub-identity structure while this type of identity may be seen not in the general sample of student athletes but in several sub-groups or individuals.

\section{References}

Arnett J. J. (2007) Emerging adulthood: What is it, and what is it good for? Child Development Perspectives, 1, 68-73. DOI: https://doi.org/10.1111/j.1750-8606.2007.00016.x

Brewer B. W. \& Cornelius A. E. (2001). Norms and factorial invariance of the Athletic Identity Measurement Scale. Academic Athletic Journal, 15, 103-113.

Brewer, B. W., Van Raalte, J. L. \& Linder, D. E. (1993). Athletic identity: Hercules' muscles or achules heel? International Journal of Sport Psychology, 24(2), 237-254. DOI: https://doi.org/10.1037/t15488-000

Brewer, B.W. \& Petitpas, A. J. (2017). Athletic identity foreclosure. Current Opinion in Psychology, 16, 118-122. DOI: https://doi.org/10.1016/j.copsyc.2017.05.004

Brown, C., Glastetter-Fender, C. \& Shelton, M. (2000). Psychological identity and career control in college student-athletes. Journal of Vocational Behavior, 56(1), 53-62. DOI: https://doi.org/10.1006/jvbe.1999.1691

Para citar este artículo utilice la siguiente referencia: Berkcan, B.; Kiremitci, O. (2021). So called athletic identity, incompatible with reality: Static identity structure, status transitions and health behaviour dynamics in student athletes. Sportis Sci J, 7 (1), 67-90. https://doi.org/10.17979/sportis.2021.7.1.6918 http://revistas.udc.es/ 
Artículo Original. So called athletic identity, incompatible with reality: Static identity structure, status transitions and health behaviour dynamics in student athletes. Vol. 7, n. ${ }^{\circ} 1$; p. 67-90, enero 2021. A Coruña. España ISSN 2386-8333

Buckley, G. L., Hall, L. E., Lassemillante, A. M., Ackerman, K. E. \& Belski, R. (2019). Retired Athletes and the Intersection of Food and Body: A Systematic Literature Review Exploring Compensatory Behaviours and Body Change. Nutrients, 11(6), 1395. DOI: https://doi.org/10.3390/nu11061395

Çebi, M., Eliöz, M., Yamak, B., Imamoglu, O. \& Aksoy, Y. (2020). Investigation of food consumption frequency in sports faculty students. Progress in Nutrition, 22 (2), 507-514. DOI: https://doi.org/10.23751/pn.v22i2.9253

Chin, J. W., Johnson, J., Signer-Kroeker, M. A. \& Holman, M. (2020). From the bottom of a bottle: A sociological examination of the use of alcohol in varsity sport hazing, International Review for the Sociology of Sport, 55(7), 991-1008. DOI: https://doi.org/10.1177/1012690219861607

Cohen, J. (1988). Statistical power analysis for the behavioral sciences (2 $2^{\text {nd }}$ ed.). New Jersey: Lawrence Earlbaum Associates.

Cosh, S. \& Tully, P. J. (2014). “All I have to do is pass”: a discursive analysis ofstudent athletes' talk about prioritising sport to the detriment of education to overcome stressors encountered in combining elite sport and tertiary education. Psychology of Sport and Exercise, 15(2) ,180-189. DOI: https://doi.org/10.1016/j.psychsport.2013.10.015

Field, A. (2009). Discovering statistics using Spss (3rd ed.). London: Sage.

Foster, S. \& Huml, M. R. (2017). The Relationship Between Athletic Identity and Academic Major Chosen by Student-Athletes. International Journal of Exercise Science, 10(6), 915925.

Grove, J. R., Fish, M. \& Ekiund, R. C. (2004). Changes in athletic identity following team selection: Self-protection versus self-enhancement. Journal of Applied Sport Psychology, 16 (1), 75-81. DOI: https://doi.org/10.1080/10413200490260062

Houle, J. L, Brewer, B. W. \& Kluck, A.S. (2010). Developmental Trends in Athletic Identity: A Two-Part Retrospective Study. Journal of Sport Behavior, 33(2), 146-159.

Gomez, J., Bradley, J. \& Conway, P. (2018) The challenges of a high-performance student athlete. Irish Educational Studies, 37(3), 329-349. DOI: https://doi.org/10.1080/03323315.2018.1484299 
Artículo Original. So called athletic identity, incompatible with reality: Static identity structure, status transitions and health behaviour dynamics in student athletes. Vol. 7, n. ${ }^{\circ} 1$; p. 67-90, enero 2021. A Coruña. España ISSN 2386-8333

Jewett, R., Kerr, G. \& Tamminen, K. (2019) University sport retirement and athlete mental health: A narrative analysis, Qualitative Research in Sport, Exercise and Health, 11(3), 416-433, DOI: https://doi.org/10.1080/2159676X.2018.1506497

Jolly, J. C. (2008) Raising the Question \# 9 Is the Student-Athlete Population Unique ? and Why Should We Care? Communication Education, 57(1), 145-151. DOI: https://doi.org/10.1080/03634520701613676

Kerr, Z. Y., DeFreese, J. D. \& Marshall, S. W. (2014). Current Physical and Mental Health of Former Collegiate Athletes. Orthopaedic Journal of Sports Medicine, 2(8), 1-9. DOI: https://doi.org/10.1177/2325967114544107

Linnemeyer, R. M. \& Brown, C. (2010). Career maturity and foreclosure in student athletes, fine arts students, and general college students. Journal of Career Development, 37(3), 616634. DOI: https://doi.org/10.1177/0894845309357049

Linner, L., Stambulova, N., Storm, L.K., Kuettel, A. \& Henriksen, K. (2020). Facilitating Sports and University Study: The Case of a Dual Career Development Environment in Sweden. Case Studies in Sport and Exercise Psychology, 4(1), 95-107. DOI: https://doi.org/10.1123/cssep.2020-0011

Mateu, P., Inglés, E., Torregrossa, M., Marques, R., Stambulova, N. \& Vilanova, A. (2020). Living Life Through Sport: The Transition of Elite Spanish Student-Athletes to a University Degree in Physical Activity and Sports Sciences. Frontiers in psychology, 11, 1367. DOI: https://doi.org/10.3389/fpsyg.2020.01367

Maulini, C., Di Palma, D. \& Ascione, A. (2020). Educational counseling in the dual career of athletes-students. Sport Science, 13(1), 64-69.

Menke, D. J. \& Germany, M. (2019). Reconstructing Athletic Identity: College Athletes and Sport Retirement, Journal of Loss and Trauma, 24 (1), 17-30, DOI: https://doi.org/10.1080/15325024.2018.1522475

Merkel, D. L. (2013). Youth sport: positive and negative impact on young athletes. Open Access Journal of Sports Medicine, 4, 151-160. DOI: https://doi.org/10.2147/OAJSM.S33556

Miller, P. S. \& Kerr, G A. (2003). The Role experimentation of intercollegiate student athletes. The Sport Psychologist, 17(2), 196-219. DOI: https://doi.org/10.1123/tsp.17.2.196

Murphy, S. M., Petitpas, A. J. \& Brewer, B. W. (1996). Identity foreclosure, athletic identity, and career maturity in intercollegiate athletes. The Sport Psychologist, 10(3), 239-246. DOI: 


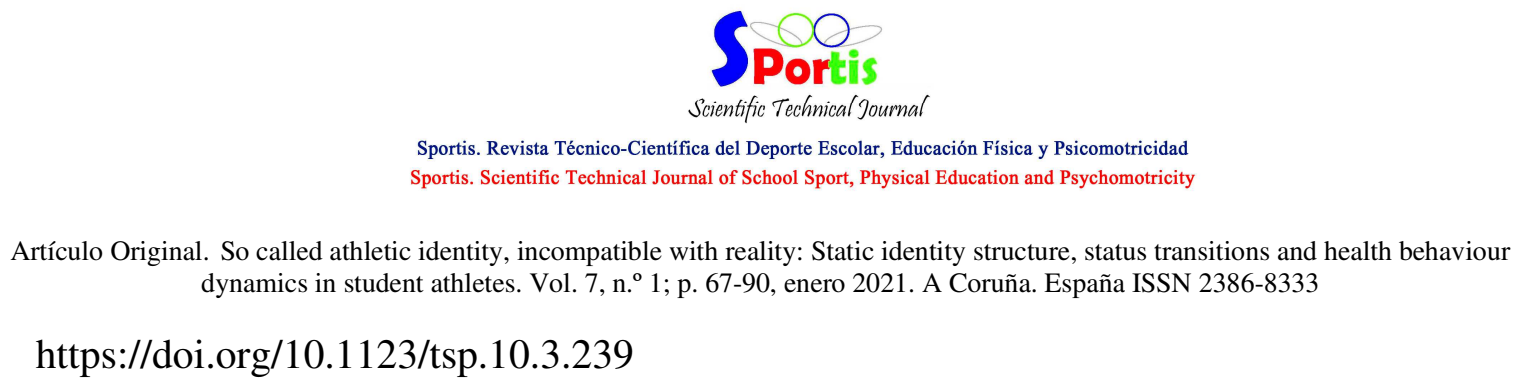

Öztürk, P. \& Koca, C. (2013). Examining psychometric properties of the Turkish version of Athletic Identity Measurement Scale. Hacettepe Journal of Sport Sciences, 24(1), 1-10.

Palermo, M., Choquette, E. M., Ahlich, E. \& Rancourt, D. (2020). Food and alcohol disturbance by athlete status: The roles of drive for thinness, drive for muscularity, and sex. Journal of American College Health, 1-8. DOI: https://doi.org/10.1080/07448481.2020.1713791

Reifsteck, E. J., Gill, D. L. \& Labban, J. D. (2016). “Athletes" and "exercisers": Understanding identity, motivation, and physical activity participation in former college athletes. Sport, Exercise, and Performance Psychology, 5(1), 25-38. DOI: https://doi.org/10.1037/spy0000046

Reifsteck, E. J., Gill, D. L. \& Brooks, D. L. (2013). The relationship between athletic identity and physical activity among former college athletes. Athletic Insight, 5(3), 271-284. DOI: https://doi.org/10.1037/spy0000046

Rongen, F., McKenna, J., Cobley, S., Tee, J. C. \& Till, K. (2020) Psychosocial outcomes associated with soccer academy involvement: Longitudinal comparisons against aged matched school pupils, Journal of Sports Sciences, 38 (11-12), 1387-1398, DOI: https://doi.org/10.1080/02640414.2020.1778354

Ronkainen, N. J., Kavoura, A. \& Ryba, T. V. (2016). A meta-study of athletic identity research in sport psychology: Current status and future directions. International Review of Sport and Exercise Psychology, 9(1), 45-64. DOI: https://doi.org/10.1080/1750984X.2015.1096414

Shachar, B., Brewer, B. Cornelius, A. E. \& Petitpas, A. J. (2004). Career decision-making, athletic identity, and adjustment difficulties among retired athletes: A comparison between coaches and non-coaches. Kinesiologia Slovenica, 10(1), 71-85.

Shriver, L. H., Reifsteck, E. J. \& Brooks, D. (2019). Moving On!: A Transition Program for Promoting Healthy Eating and an Active Lifestyle Among Student-Athletes After College. Journal of Nutrition Education and Behavior, 51(1), 112-115. DOI: https://doi.org/10.1016/j.jneb.2018.08.004

Simon, J. E. \& Docherty, C. L. (2017). The Impact of Previous Athletic Experience on Current Physical Fitness in Former Collegiate Athletes and Noncollegiate Athletes. Sports Health, 9(5), 462-468. DOI: https://doi.org/10.1177/1941738117705311

Stambulova N. B. \& Wylleman P. (2019). Psychology of athletes' dual careers: A state-of-the-art

Para citar este artículo utilice la siguiente referencia: Berkcan, B.; Kiremitci, O. (2021). So called athletic identity, incompatible with reality: Static identity structure, status transitions and health behaviour dynamics in student athletes. Sportis Sci J, 7 (1), 67-90. https://doi.org/10.17979/sportis.2021.7.1.6918 http://revistas.udc.es/ 
Artículo Original. So called athletic identity, incompatible with reality: Static identity structure, status transitions and health behaviour dynamics in student athletes. Vol. 7, n. ${ }^{\circ} 1$; p. 67-90, enero 2021. A Coruña. España ISSN 2386-8333

critical review of the European discourse. Psychology of Sport and Exercise, 42, 74-88. DOI: https://doi.org/10.1016/j.psychsport.2018.11.013

Stambulova, N. B., Engström, C., Franck, A., Linnér L. \& Lindahl, K. (2015). Searching for an optimal balance: Dual career experiences of Swedish adolescent athletes, Psychology of Sport and Exercise, 21, 4-14. DOI: https://doi.org/10.1016/j.psychsport.2014.08.009

Sutcliffe, J. H. \& Greenberger, P. A.(2020). Identifying Psychological Difficulties in College Athletes. Journal of Allergy and Clinical Immunology: In Practice, 8(7), 2216-2219. DOI: https://doi.org/10.1016/j.jaip.2020.03.006

Tracey, J. \& Elcombe, T. (2004). A Lifetime of Healthy Meaningful Movement: Have We Forgotten the Athletes?, Quest, 56(2), 241-260. DOI: https://doi.org/10.1080/00336297.2004.10491825

Van Rens, F.E., Ashley, R.A. \& Steele, A. (2019). Well-Being and Performance in Dual Careers: The Role of Academic and Athletic Identities. Sport Psychologist, 33(1), 42-51. DOI: https://doi.org/10.1123/tsp.2018-0026

Walton, C. C., Baranoff, J., Gilbert, P. \& Kirby, J. (2020). Self-compassion, social rank, and psychological distress in athletes of varying competitive levels, Psychology of Sport and Exercise,50, 101733. DOI: https://doi.org/10.1016/j.psychsport.2020.101733

Webb, W. M., Nasco, S. A., Riley, S. \& Headrick, B. (1998). Athlete identity and reactions to retirement from sports. Journal of Sport Behavior, 21(3), 338-362.

Wippert, P. \& Wippert, J. (2008). Perceived stress and prevalence of traumatic stress symptoms following athletic career termination. Journal of Clinical Sport Psychology, 2(1), 1-16. DOI: https://doi.org/10.1123/jcsp.2.1.1

Xanthopoulos, M.S., Benton, T., Lewis, J. \& Case, J. A. (2020). Mental Health in the Young Athlete. Current Psychiatry Reports, 22(11), 63 (2020). DOI: https://doi.org/10.1007/s11920-020-01185-w 